\title{
Miranda
}

Revue pluridisciplinaire du monde anglophone /

Multidisciplinary peer-reviewed journal on the English-

speaking world

19 | 2019

Rethinking Laughter in Contemporary Anglophone Theatre

\section{Rethinking Laughter in Contemporary Anglophone Theatre}

Sophie Maruejouls

\section{(2) OpenEdition}

Journals

Electronic version

URL: http://journals.openedition.org/miranda/19889

DOI: 10.4000/miranda.19889

ISSN: 2108-6559

\section{Publisher}

Université Toulouse - Jean Jaurès

Printed version

Date of publication: 7 October 2019

\section{Electronic reference}

Sophie Maruejouls, "Rethinking Laughter in Contemporary Anglophone Theatre", Miranda [Online], 19 |

2019, Online since 09 October 2019, connection on 16 February 2021. URL: http://

journals.openedition.org/miranda/19889; DOI: https://doi.org/10.4000/miranda.19889

This text was automatically generated on 16 February 2021.

\section{(c) (i) (3)}

Miranda is licensed under a Creative Commons Attribution-NonCommercial-NoDerivatives 4.0 International License. 


\title{
Rethinking Laughter in Contemporary Anglophone Theatre
}

\author{
Sophie Maruejouls
}

1 The revival on the contemporary stage of long-established aesthetic categories inherited from the comic tradition and comprising a wide variety of styles, ranging from the burlesque, the slapstick or the farcical to satirical and black comedies, calls for a re-examination of the role and function of laughter in anglophone theatre since the second half of the twentieth century. In a post-Auschwitz world where, according to Theodor Adorno's much-quoted dictum, it has become impossible to write poetry, the diversity of comic forms seems to have provided playwrights with the means of filling the void of the unspeakable. As early as 1958, Ionesco felt the need for a theatrical medium that had to be violently comical, that had "to push everything to paroxysm, to the point where the sources of the tragic lie" (Ionesco quoted in Esslin 142). In this light, the comic voice, as it manifests itself on stage today, could prove to be the catalyst for a new understanding of the tragic. This idea was suggested by Mireille Losco-Lena in 2005, when she wrote that the use of comic forms could breathe new life into theatre and help redefine the tragic (249). So, if it is still possible for spectators to laugh today, what makes them laugh? What is the meaning of the bursting, inarticulate voice that shakes them? Is it simply the only possible answer to the strangeness of the world, to its radical inhumanity? Or, in that shared space created by laughter, couldn't there be a desire to go beyond nihilism and an affirmation of humanity? The Rabelaisian experience of laughter as pure outburst or Baudelaire's description of the intoxicating power of laughter seem indeed to hint at something absolute, "something terrible and irresistible" (Baudelaire 156) that unsettles the relation of the public to the spectacle and renews the comic tradition to expand the potentialities of laughter, making it not just "the only imaginable and definitively terminal result" (Bataille 99), but also a means of setting thought in motion and continuing to be human in a world that no longer seems to be so.

2 The use of the term "contemporary" has to be understood as covering the period from the Second World War to today, a period marked by the horrors of two world wars, by 
the widening of the gap between the rich and the poor, by climate change, by the gradual extinction of animal species, by terrorism... the list is long and could be even longer. Yet, through these troubled times, the comic form has developed into a highly reflective mode of understanding and representing the real. It has become a means of making sense of a multi-faceted, complex and ever-changing world whose propensity for not making sense, whose absurdity, resists our interpretative power, our need for coherence and order, a world that leaves us at times with only two options: laughing or crying. In its multiplicity of forms, motives and effects, laughter remains a highly enigmatic, highly theatrical externalization of something that cannot be named, which is why plays that make us laugh cannot simply be categorized as light-hearted art that refuses to take part in the violence of the world. After all, it is that violence that prompted such art, and it is because artists refused that violence that they chose to laugh at it.

3 Each contribution examines laughter from a specific angle, providing new insights on the political, cultural, ethical and mythical implications of laughter on contemporary British and American stages. Each offers us a glimpse of our times through the lens of humour, revealing the endless potentialities of the comic voice, its capacity for renewal and for addressing a wide range of audiences.

Elisabeth Angel-Perez demonstrates how post-Beckettian playwrights use wit as a new locus for tragedy to relocate, stretching the limits of language to produce a new form of laughter. Described as "horrendhilarious," it is a laughter that bursts in the midst of horror, a laughter characteristic of a neo-satiricist tendency inherited from the theatrical and verbal experimentations of Samuel Beckett and Harold Pinter. Her exploration of the way the innovative, politically committed playwrights of the last two decades have dealt with language, pushing its metaphorizing process to its limits while liberating it from the constraints of visual representation, sheds light on the infinite potentialities of wit as a political tool and as a central device in what has come to be known as In-Yer-Ear theatre.

5 In her analysis of American playwright Robert Askins's play Hand to God, Marianne Drugeon explores the intricate connections tying comedy to tragedy. Drawing upon Bergson's famous essay on laughter, Drugeon further extends the philosopher's definition of comedy as mechanical repetition to shed light on Askins's use of puppets, revealing the originality of a playwright influenced both by a post-modern, American tradition inherited from Edward Albee and by British In-Yer-Face theatre. The combination of the funny and the disturbing in Askins's play is given particular attention, providing new insights into the regenerative power of the comic form as a means of putting thought in motion and creating alternative ways of seeing the world. Drugeon's final comparison of the various venues for the play, from off-Broadway to Broadway, then to London and Paris gives a broader perspective on the different types of laughter induced by different types of staging, inviting further reflexion on the reception of comic plays.

Claire Hélie's contribution focuses on British-Canadian playwright Evan Placey's theatre for young audiences. Using research in psychology, her identification of the different types of adolescent laughter present in Placey's texts brings to light both the exclusive and cohesive functions of humour. Analysing the modalities of laughter in the stage directions and in performance, she demonstrates how laughter participates in the creation of a "youth effect" that reaches the audience through the maintaining of a 
constant tension between distancing and empathy, laughter eventually serving as a means of involving the public into the aesthetic and ethical issues raised by the plays.

7 Xavier Lemoine's article on queer laughter offers a well-documented and comprehensive overview of the history of queer stand-up from the 1960s until now in the United States. The variety of artists and shows mentioned richly illustrates the author's argument, providing the reader with a new angle of perspective from which to approach queer studies. Drawing upon scholars Michael Warner, José Esteban Munoz and Jean Luc Nancy, to name a few, Lemoine explores such notions as "counterpublic," "disidentification" or "presence" to find a theoretical ground for laughter and queerness to meet. Laughter as outburst, as something ephemeral and unfixed, belongs to the margins of humanity, to those moving limits that allow for the emergence of a queer subjectivity. As a privileged space where new horizons can be glimpsed at, the comic stage, queer stand-up especially, is reappraised by the author in order to bring to light its aesthetic as well as political potential and the significant part it has played in the transformation of American culture from the 1960s on.

8 Emmanuel Vernadakis's analysis of Tennessee Williams's ambivalent sense of laughter through the 1948 play Summer and Smoke and two short stories written around the same period explores the many layers of intertextuality present in Williams's writing in order to shed light on the salutary, haunting authority of a laughter that originates in autobiographical material. Positing the gesture of anasyrma as a central, verbal as well as performative device in Williams's theatre, Vernadakis traces the origins of the American playwright's literary influences back to ancient Attic comedies, relating Williams's use of puns to Aristophanes's own mastery of language. The multiplicity of hidden meanings and influences that reverberates through Williams's texts are thus brought to the surface in an in-depth study that reveals the multi-layered dimension of Williams's comic voice, a voice that multiplies and overdramatizes the sense of "I" in order to bridge the gap between art and life, a voice that produces an ambivalent form of laughter, both apotropaic in its liberating, regenerative function and tragic in its stemming from a censored sexuality.

\section{BIBLIOGRAPHY}

Adorno, Theodor W. "Cultural Criticism and Society." Prisms. Trads. Samuel et Shierry Weber. Cambridge, MA: MIT Press, 1983: 17-34.

Bataille, Georges. "The Use and Value of D. A. F. de Sade." Ed. Allan Stoekl. Trads. Carl R. Lovitt et Donald M. Leslie. In Theory and History of Literature (Vol. 14). Minneapolis: University of Minnesota Press (1985): 91-105.

Baudelaire, Charles. "Of the Essence of Laughter, and Generally of the Comic in the Plastic Arts." In Baudelaire Selected Writings on Art and Artists. Trad. P. E. Charvet. New York: Cambridge University Press (1972): 140-162.

Esslin, Martin. The Theatre of the Absurd. New York: Random House (1961), 2004. 
Losco-Lena, Mireille. « FoRire, chaos, désastre : vers un nouvel espace comique dans le théâtre contemporain ». Recherches \& Travaux (N67), 2005: 239-249.

\section{AUTHOR}

SOPHIE MARUEJOULS

Maître de conférences

Université de Toulouse Jean Jaurès

sophie.maruejouls@live.fr 